\title{
The Use of Anglicisms in Spanish Television Commercials of Cosmetics, Hygiene and Personal Care Products
}

\begin{abstract}
This paper analyses the use of English in Spanish television commercials, since no scientific studies have been carried out so far in this field. Although there are a few similar studies of print media, our review of the literature has shown some gaps in the research on Anglicisms used in advertising. English seems to be widely present in television commercials in Spain for different reasons. Marketing and cost-saving strategies of multinational companies together with the prestige of the English language and Anglo-American culture in Spain are some of the primary causes. In our study, we have focused on a corpus of pure Anglicisms (English words which have not been adapted to Spanish) and pseudo-Anglicisms (terms that do not exist in English, though they are similar to English words), found in commercials related to cosmetics, hygiene and personal care products, as part of the research project "Globalisation and Impact of the Anglo-American Culture on Spain”. Five hundred and thirty one commercials of the three main private national television channels in Spain (Tele5, Antena3, LaSexta) and children's Disney Channel (Spain) were compiled in 2013. The results confirm a considerable presence of pure Anglicisms, English-Spanish code switching, pseudo-Anglicisms and Anglo-American imagery and music in the advertising of products related to cosmetics, hygiene and personal care on Spanish television. Consequently, the link of these products to the prestige of the English-speaking world is reinforced.
\end{abstract}

\section{Keywords}

Anglicisms, advertising, marketing, English, Spanish, globalisation, television commercials.

\section{Introduction}

Although social networks such as Facebook and Twitter are now being used extensively as efficient ways of advertising products to millions of potential consumers (Beckwith 2008: 27), television is still one of the most popular and successful communication media to sell products in Spain. Martínez (2005: 45) explains that "people are far more vulnerable to audiovisual language, whose sudden impact is easy to assimilate, than to mere verbal messages that demand conceptual understanding and reflection. They are always uncertain slow processes. Thus, audiovisual language is generally ideal to meet the commercial aims of advertising"’.

The different psycholinguistic procedures used to persuade a particular audience to buy a product or service have been widely analysed and discussed. The highly connotative, emotive and expressive terms of the advertising world contribute to magnify the product's excellence and persuade the consumer to buy it. In the case of television, the persuasive role of images is fundamental to sell the product, since a multiplicity of messages is transmitted simultaneously. As Hernández (2008: 226) argues, "typography, colour and format usually become a visual show aimed at making an impact on viewers and catch their attention. Television advertising is also

1 All references written in Spanish have been translated into English by this paper's author.

\footnotetext{
* Dr María Jesús Rodríguez-Medina

Universidad de Las Palmas de Gran Canaria

Departamento de Filología Moderna

Calle Pérez del Toro 1

35003 Las Palmas de Gran Canaria

Spain

mariajesus.rodriguez@ulpgc.es
} 
very expensive. Therefore, it demands constant innovation and a series of sophisticated strategies to avoid causing impression of repetition to viewers".

Foreign terms are a very common resource in television advertising where songs and attractive voices in other languages are very appealing. This is a common feature of all advertising media in Spain since it is a way to transgress the norm and attract attention (Rodríguez Díaz 2011: 173). In fact, exotisms (including foreign words) are frequently used to catch the attention of potential customers (González et al. 2009: 45). English words, phrases, slogans and songs are regularly included in Spanish television commercials, except in the case of particular products (e.g. perfumes) where French and Italian may be preferred for reasons that will be discussed in this paper.

\section{An Overview of Anglicisms in Spanish}

\subsection{Background}

Since the last half of the twentieth century the study of Anglicisms in European Spanish has been significant in linguistic research. In Spain, Emilio Lorenzo was undoubtedly a pioneer in this domain. "El anglicismo en la España de hoy" (“Anglicisms in today’s Spain”), first published in 1955, dealt with the need to analyse a phenomenon that he described as "linguistically, socially and nationally relevant". In this early period linguists were alarmed by the growing presence of Anglicisms in Spanish and their main intention was to prevent their use.

Most scholars agree that the modern understanding of Anglicism can be attributed to Pratt and his influential book on Anglicisms in contemporary Spanish (1980). Pratt (1980: 115-212) offered a precise scientific definition and classification of the concept, and his distinction between patent and non-patent Anglicisms is still commonly found in research related to this field.

While scientific interest in this subject wanes somewhat during the 1980s, a new sociolinguistic approach can be observed in the academic literature. According to Gómez Capuz (1997: 30), at the beginning of the 1990s, "we can certainly regard the phenomenon of Anglicisms as being already mature in Spanish". In fact, linguists adopted a moderate attitude and publications were fundamentally descriptive (Medina López 1996, Rodríguez Segura 1999).

In the new millennium a considerable number of works on Anglicisms in specialised fields (medicine, economy, cinema, etc.) have been published. Different monographs are also available (Rodríguez Medina 2003, Pirulli 2004, García 2009). Nevertheless, although the influence of the English language on television commercials in Spain seems to be clear, no scientific studies have so far been conducted in this field, except for the analysis of Anglicisms present in television commercials of perfumes published by Rodríguez-Medina in the past decade (2001). In fact, this is the only publication on Anglicisms used in cosmetics, hygiene and personal care commercials in Spain. Thus, academic interest appears to have been focused on print media. The presence of English in advertisements appearing in the most important Spanish newspapers was examined by Durán (2002) who was a pioneer in this area. In 2006, Van Hooft also studied the use of Anglicisms in the Spanish edition of the fashion magazine Elle. Gerritsen et al. (2007) published the results of their research on the use of English in different European fashion magazines (Belgium, France, Germany, the Netherlands and Spain). In 2011 Rodríguez Díaz analysed the presence of English and German words in advertisements appearing in Spanish newspapers over a ten-year period (1998-2007). Recently, Valozic (2015) has updated Durán’s and Rodríguez Díaz’s monographs in a similar study focused on advertisements found in the Spanish print media, although it also includes a corpus of Italian, French and Serbian newspapers.

As this review demonstrates, research on Anglicisms has been significant, but it has only superficially addressed the advertising of cosmetics, hygiene and personal care products on television. Hence, there is still an important gap in the research on Anglicisms in the Spanish media. This paper is mainly aimed at filling this gap with an analysis of a recent corpus of commercials of the main Spanish television channels. 


\subsection{Reasons why Anglicisms are very frequent in the world of Spanish advertising}

\subsubsection{Prestige}

As has been the trend in most Western cultures, English is regarded as a prestige language in Spain (González et al. 2009: 14). Rodríguez González (2012: 295) points out that "the prestige of English in today's world has contributed to the fact that most Anglicisms are used in their original form". He had confirmed this prestige of English in Spain since the 1990s: "in our times English [...] confers prestige and positive connotations to its borrowings” (Rodríguez González 1996: 114).

English inspires the commercial names and trademarks of many Spanish companies. This marketing strategy has proved to be efficient in the Spanish marketplace to symbolise status, efficiency and modernity (González et al. 2009: 45). Thus, Rodríguez Díaz (2011: 174) argues that "the use of foreign graphs and signs associates the product with the prestige of foreign countries in Spain". There are some well-known examples of this such as the Spanish trademarks Springfield or Pull\&Bear. This growing tendency suggests that Spanish consumers are keen on products named in English, and they seem to prefer foreign trademarks (Bassat 2006: 185). However, Rodríguez-Medina (2001: 690) observed that other languages such as French and Italian are also used to advertise the most expensive perfumes. In the Spanish market of perfumes, English was exclusively used in commercials for low-price products at the end of the 1990s. The situation is very likely to have changed after so many years, so it needs to be updated.

\subsubsection{American dominance}

Some of the leading advertising multinational companies are American. As Valozic states (2015: 63), "they launch 'global' campaigns in English in all their markets", where English acts as a lingua franca. Globalisation promoted by the mass media and similarities observed in the habits of European consumers have probably favoured this tendency. It was called 'McDonaldization' by Baumgardner and basically denotes a preference of English in the name of products, campaigns, brands and slogans, together with the popularization of American gestures, habits, cultural symbols and imagery (González et al. 2009: 48).

English is used to highlight the American qualities of the product which are usually linked to positive connotations due to the economic supremacy of the US (Rodríguez Díaz 2011: 171172). For instance, fast food firms will consistently play on words related to the names of their trademarks:

(1) Burger King, el sabor es el King; Enamórate de la novedad de King Ahorro².

Furthermore, most Spaniards are normally familiar with these products thanks to Hollywood films and the enormous popularity of American television series in Spain. On the other hand, we cannot forget legal aspects such as trademark copyrights, which protect products against the unauthorized manipulation or translation of their names and slogans. However, there are no Spanish laws limiting the use of foreign languages in advertising such as France’s Toubon law.

\subsubsection{Tecnicisms and neologisms}

The permeability of advertising language to tecnicisms and neologisms favours the use of English (Rodríguez Díaz 2011: 73), especially with certain products such as anti-aging creams (Biotherm Blue Therapy), shampoos (L'Oréal Elvive Total Repair), deodorants (Rexona con tecnología Motion Sense) and toothpaste (Sensodyne Repair\& Protect), among others. Some of these terms (Revitalift, Regenerist) are pseudo-Anglicisms, considered as 'stylistic neologisms'. Latin and Greek words or prefixes and suffixes are also used. These words do not exist in English and are described

2 All the examples in these sections (2.2.3, 2.2.4 and 2.2.5) are taken from our corpus. Burger King, Taste is King. Fall in love with the new Saving King. 
as expressive terms. They are full of bizarre linguistic alterations with positive connotations of prestige and scientific efficiency and accuracy.

\subsubsection{Flexibility}

There is an abundance of sonorous monosyllabic words in English which can form plenty of lexical compounds and structures. This flexibility favours their use in slogans and product packaging, since advertising is normally based on fast and efficient communication, known as advertising economy (Rodríguez Díaz 2011: 176). Slogans and company mottos must be short, expressive and easy to memorise. For instance, new instead of nuevo or smartphone instead of teléfono inteligente are frequent in our corpus.

\subsubsection{Linguistic snobbery}

Sometimes Anglicisms are present in advertisements just out of linguistic snobbery, especially when the product is targeted at young people. As Durán (2002: 179) explains, "the advertiser often tries to flatter the target, presenting the advertisement in English with relatively known words which are similar to their Spanish equivalents. The interpretation of these easy-to-translate short texts provokes a high satisfaction in the target, who feels included in the group of people that can understand English".

For instance, advertisers know that Spanish youngsters sometimes use Anglicisms just for the fun of it. English is attractive to them, since they associate it with modernity, technology, design, good music, international social networks, drinks and activities they generally enjoy. Hence, Anglicisms often appear in advertisements as an attention-grabbing device effective in circumventing youngsters' indifference and distrust and building rapport with young viewers. Youngsters are proud of understanding these advertisements and consequently feel positive emotions towards the advertised product (González et al. 2009: 59).

\subsection{Research questions}

The following research questions are aimed at filling the perceived gaps:

1. Are Anglicisms used to express positive connotations of prestige in commercials related to cosmetics, hygiene and personal care products?

2. Are Anglo-American images and songs present in these commercials?

3. Do play on words, phonetic effects, orthographic alterations, the use of Latin or Greek words, prefixes or suffixes, bizarre or unusual combinations of English words, and code-switching in English and Spanish function as exotic and original linguistic resources to catch the attention of the viewer?

4. Are French and Italian and other languages, which have been traditionally linked to luxury and good taste in the Spanish perfume market, still used to advertise for the most expensive perfumes?

\section{Methodology}

This study is part of the research project "Globalisation and Impact of the Anglo-American Culture on Spain" which started in June $2013^{3}$. As it has been explained, the main aim of this project is to determine the presence and nature of Anglo-American cultural signifiers in Spanish television commercials, especially in advertising on prime-time programming.

3 The members of the project are Dr Carmen Luján García, Dr María Jesús Rodríguez-Medina, Dr María Isabel González Cruz and Dr Goretti García Morales. 
Commercials from the three main private national television channels in Spain (Tele5, Antena3, LaSexta) and children's Disney Channel (Spain) were compiled during one week in the summer of 2013 (July $15^{\text {th }}-21^{\text {th }}$ ) and during the Christmas week of that year (December $16^{\text {th }}-22^{\text {nd }}$ ). The commercials were aired from 4 to 5:30 p.m. and 8:30 to 11:30 p.m. This allowed us to obtain data from two different periods of the year when commercials are aired in greatest number. Products related to holidays (online travel agencies, theme parks, etc.), and sales (special offers by the main Spanish department stores and shops) are very popular in Spain in summer time. As a result, advertising becomes more intense especially in July, since August is the traditional month for holidays in this country. Besides, the number of commercials increases dramatically at Christmas for obvious reasons.

31.5 hours of prime-time television were recorded from each of the four channels across the two chosen weeks in July and December. Additionally, we recorded 126 hours of advertising in July and 126 in December (252 hours). Descriptions of each commercial (entirely done in English or containing Anglicisms, Gallicisms or Italianisms) were recorded in a Word file, structured with the following entries: type of product announced; trademark; brief description of the commercial; type of message (oral, written or both); timetable; channel; period (July/December); recording day of the week; Anglo-American elements (music, clothes, flags, food, etc.); loanwords (Anglicisms, Gallicisms, Italianisms, other); observations.

These contextual data were considered essential in order to have as much information as possible about all the analysed commercials. Repetitions of the same commercial in different channels were not included.

Commercials were classified into four different groups: (1) children's products, (2) cars and insurance companies; (3) new technologies, leisure and food; (4) cosmetics, hygiene and personal care. Due to the considerable size of the corpus (531 commercials), the analysis of these four groups of commercials was distributed among the members of the project. However, this article only accounts for the analysis of Anglicisms found in commercials related to cosmetics, hygiene and personal care. Since Anglicisms completely adapted to the Spanish language were excluded from the compilation, we considered as Anglicisms only those English words that are used either in their original form or are semi-adapted to the Spanish language and classified them as follows (Rodríguez-Medina 2014: 407):

- Pure Anglicisms. Words used in their original form in English with no adaptation.

- Pseudo-Anglicisms or false Anglicisms. English-looking words which do not exist in English.

- Partially assimilated Anglicisms. English words whose morphology is only partially adapted to Spanish.

\section{Results and interpretation}

\subsection{Analysis of the corpus}

Firstly, the analysis will be presented in general terms before we discuss the specific characteristics of the Anglicisms found in the different types of products advertised. We found a total of 112 commercials with Anglicisms or English used as the main language in the field of cosmetics, hygiene and personal care products. They were distributed as follows: 


\begin{tabular}{|l|c|}
\hline \multicolumn{1}{|c|}{ TYPE OF PRODUCT } & $\begin{array}{c}\text { TOTAL } \\
\text { NUMBER }\end{array}$ \\
\hline 1. Perfumes & 41 \\
\hline 2. Anti-aging and sun creams & 17 \\
\hline 3. Shampoos and hair products & 17 \\
\hline 4. Deodorants & 6 \\
\hline 5. Razors and electric shavers & 6 \\
\hline 6. Clothes and lingerie & 6 \\
\hline 7.Toothpaste and mouthwash & 6 \\
\hline 8. Health products & 4 \\
\hline 9. Sanitary towels and tampons & 4 \\
\hline 10. Mascara and make-up & 5 \\
\hline \multicolumn{2}{|c|}{ Total: } \\
\hline
\end{tabular}

Table 1. Commercials entirely in English or including Anglicisms

As table 1 shows, English was used in the commercials for 10 different types of products. A total of 212 Anglicisms were recorded in 112 commercials. As we can see from table 2, perfumes (31.61\%) and anti-aging creams (20.28\%) were the products with the greatest content of English, followed by shampoos and hair products (10.37\%), razors and electric shavers (9.43\%), deodorants (6.61\%), mascara and make-up (5.66\%), toothpaste and mouthwash (5.18\%), clothes and lingerie $(4.71 \%)$, health products (3.77\%) and sanitary towels and tampons (2.35\%).

\begin{tabular}{|l|c|c|c|c|}
\hline \multicolumn{1}{|c|}{$\begin{array}{c}\text { TYPE OF PRODUCT } \\
\text { ANGLICISMS }\end{array}$} & $\%$ & $\begin{array}{c}\text { PURE } \\
\text { ANGLICISMS }\end{array}$ & $\begin{array}{c}\text { PSEUDO- } \\
\text { ANGLICISMS }\end{array}$ \\
\hline 1. Perfumes & 67 & $31.61 \%$ & 67 & - \\
\hline 2. Anti-aging and sun creams & 43 & $20.28 \%$ & 35 & 8 \\
\hline 3. Shampoos and hair products & 22 & $10.37 \%$ & 21 & 1 \\
\hline 4. Razors and electric shavers & 20 & $9.43 \%$ & 17 & 3 \\
\hline 5. Deodorants & 14 & $6.61 \%$ & 13 & 1 \\
\hline 6. Mascara and make-up & 12 & $5.66 \%$ & 11 & 1 \\
\hline 7.Toothpaste and mouthwash & 11 & $5.18 \%$ & 8 & 3 \\
\hline 8. Clothes and lingerie & 10 & $4.71 \%$ & 10 & - \\
\hline 9. Health products & 8 & $3.77 \%$ & 6 & 2 \\
\hline 10. Sanitary towels and tampons & 5 & $2.35 \%$ & 5 & - \\
\hline \multicolumn{1}{|c|}{ Total: } & 212 & & 193 & 19 \\
\hline
\end{tabular}

Table 2. Number of Anglicisms in each product category

All the products advertised entirely in English or with Anglicisms belong to multinational companies that market their products using very similar or uniform international campaigns. In fact, such standardisation is frequently part of their marketing and cost-saving strategies. Thus, the Anglo-American origin of the firm was found to be unimportant.

According to our classification of Anglicisms, 193 pure Anglicisms and 19 pseudo-Anglicisms were recorded. As table 2 shows, commercials for perfumes (67) and anti-aging creams (35), followed by shampoos and hair products (21), razors and electric shavers (17) and deodorants (13) contain the highest number of pure Anglicisms, while health products, sanitary towels and tampons are the products with the lowest frequency. It is important to notice that there are Spanish equivalents for all of these items. They are not used to fill semantic gaps, but to catch the viewers' attention for the reasons that will be discussed in the following sections.

With 8 occurrences, anti-aging creams was the product group with highest use of pseudo-Anglicisms, followed by toothpaste and mouthwash (3), and razors and electric shavers (3). This suggests that pseudo-Anglicisms are common in commercials for these products that have traditionally included technical terms in order to persuade potential consumers of the prestige of science and to catch their attention through linguistic innovation and morphological alterations. We should bear in mind that unlike pure Anglicisms, pseudo-Anglicisms are invented so they can be easily manipulated and changed. Thus, they are very useful to create English-looking pseudo-sci- 
entific words to name some products. Finally, Anglicisms partially assimilated to the Spanish language were not found in the analysed material, suggesting a clear preference for English forms unadapted to Spanish.

One relevant feature of this corpus is that Anglicisms are strongly connected to the relevant product market, i.e. most of them are unique to the product category. Anglicisms suited to emphasize the features of a product may be considered bizarre or inappropriate by advertisers or viewers in the case of other products, markets or targets. As to nouns, the few repetitions of Anglicisms observed for different types of products are shown in the following table:

\begin{tabular}{|l|c|c|c|c|c|c|c|c|c|c|}
\hline Type of product & test & men & spray & beauty & city & design & expert & skin & pack & protection \\
\hline 1. Perfumes & & $\mathrm{X}$ & $\mathrm{X}$ & $\mathrm{X}$ & $\mathrm{X}$ & $\mathrm{X}$ & & & & \\
\hline 2. Anti-aging creams & $\mathrm{X}$ & $\mathrm{X}$ & & & & & $\mathrm{X}$ & $\mathrm{X}$ & & \\
\hline 3. Hair products & $\mathrm{X}$ & & $\mathrm{X}$ & & & & & & $\mathrm{X}$ & \\
\hline 4. Razors \& shavers & & $\mathrm{X}$ & & & & & & & $\mathrm{X}$ & $\mathrm{X}$ \\
\hline 5. Deodorants & $\mathrm{X}$ & & & & & $\mathrm{X}$ & & $\mathrm{X}$ & & \\
\hline 6. Mascara \& make-up & & & & $\mathrm{X}$ & $\mathrm{X}$ & & & & & \\
\hline $\begin{array}{l}\text { 7.Toothpaste \& } \\
\text { mouthwash }\end{array}$ & & & & & & & $\mathrm{X}$ & & & $\mathrm{X}$ \\
\hline 8. Clothes \& lingerie & $\mathrm{X}$ & & & & & & & & & \\
\hline 9. Health products & & & $\mathrm{X}$ & & & & & & & \\
\hline $\begin{array}{l}\text { 10.Sanitary towels \& } \\
\text { tampons }\end{array}$ & $\mathrm{X}$ & & & & & & & & & \\
\hline
\end{tabular}

Table 3. Anglicisms observed in commercials of different types of products

Test was the most frequent noun (5 types of products), probably due to the trustworthiness and prestige of English technical and scientific references in advertising, so its positive connotations are evident. It was followed by men (3) and spray (3) which were used to specify the target and the type of product. The remaining Anglicisms (beauty, design, expert, pack, protection, expert, skin) were only repeated with two types of products. In the case of adjectives, four Anglicisms were present in different product categories: new (perfumes, creams and toothpaste); free (perfumes and toothpaste); blue (perfumes and creams) and perfect (creams and mascara). This suggests that repetition of adjectives is avoided as it may be considered unattractive by viewers.

Finally, four verbs were also repeated: protect (razors and shavers; toothpaste and mouthwash; clothes; health products); repair (anti-aging creams, hair products, toothpaste and mouthwash); be (perfumes, mascara) and make (perfumes and deodorants). The most frequent verbs (protect and repair) refer to two actions with very positive connotations (protection and repair of skin, teeth, hair, etc.).

Finally, it should be noted that the characteristics of the Anglicisms used in these commercials vary considerably depending on the type of product advertised. For the sake of illustration, two products (perfumes and creams) will be analysed in separate sections because they have the highest frequency of Anglicisms and thus amply illustrate the scope of their use. We obtained similar results for the rest of the products, so they will be treated together.

\subsubsection{Perfumes}

Spanish television commercials for these products are certainly complex. As far as foreign languages are concerned, they use mainly English, but also French, Italian and many other language combinations: 


\begin{tabular}{|l|c|}
\hline LANGUAGE COMBINATIONS & TOTAL \\
\hline 1. Entirely in English & 21 \\
\hline 2. English and Spanish & 13 \\
\hline 3. English and Spanish subtitles & 3 \\
\hline 4. English and French & 1 \\
\hline 5. English-French-Italian & 1 \\
\hline 6. English-Spanish-French-Italian & 1 \\
\hline 7. English-Spanish-Italian & 1 \\
\hline 8. Only French & 6 \\
\hline 9. French and Spanish & 5 \\
\hline 10. Only Italian & 1 \\
\hline 11. Only Spanish & 3 \\
\hline
\end{tabular}

Table 4. Languages used in perfume advertisements

A total of 21 perfume commercials, which were part of international campaigns, were entirely in English. It is remarkable that most of these perfumes are French or Italian trademarks. In a previous study (Rodríguez-Medina 2001), a growing use of English was already observed in the advertising of perfumes which is traditionally done only in French or Italian in Spain. At that time this was only observed with low-price perfumes for youngsters. However, this trend seems to have become more evident over a decade later, since now the most expensive perfumes associated with money and luxury are also advertised in English.

As we have argued, there could be several reasons for this: (1) the prestigious connotations of status and modernity associated with English in Spain today, reducing the traditionally dominant role of French and Italian in advertising luxury articles; (2) linguistic snobbery to catch the viewer's attention, and (3) the use of English as a lingua franca by multinational companies (e.g. Gucci. Made to measure. New fragance for man).

The following French and Italian luxury clothing and perfume manufacturers also opted for this kind of English-only advertising, and even the names of their perfumes were also in English in some cases:

(2) Chanel, Paco Rabanne (Lady Million, Black XS L'Excès); Gucci, Versace, Cavalli, Dolce \& Gabbana (Light Blue); Ermenegildo Zegna.

Other trademarks belong to Spanish multinational companies such as Mango (Rebel Hero, Lady Rebel) or to American brands (Ralph Lauren or Michael Kors) that clearly decided not to translate their international campaigns in Spain. These commercials usually include songs in English (e.g. Personal Jesus) and Anglo-American cultural references (e.g. New York, the Golden Gate). This also occurs in the commercials of French, Italian or Spanish firms (Paco Rabanne, Mango). Finally, three commercials completely in English but with subtitles in Spanish were also recorded (Bleu de Chanel; Chanel No 5; Dolce\&Gabbana The one).

Both English and Spanish were used in 13 commercials, a tendency regarded as usual by Valozic (2015: 122). In a few cases only the product name was in English (e.g. Code, Giorgio Arma$n i$, Italy). One particular firm exploiting this English-Spanish code-switching was Playboy (USA) which benefits from the popularity of the Anglicism corresponding to its trademark (Eres un playboy con superpoderes. SuperPlayBoy para él y para ella. First to play ${ }^{5}$.

On the other hand, the Spanish company Don algodon plays with the phonetic effect of the name of its perfume chic and sexy in Spanish, making it sound as chica sexy (sexy girl). English was also used together with Spanish, French and Italian in one commercial (Visita la nueva armanibeauty.es. La nueva eau fraîche Acqua di gioia ${ }^{6}$. Finally, an English, French and Italian

4 Perfume advertisements in French, Italian and Spanish are included here only for comparison.

5 You are a playboy with superpowers. Superplayboy for her and for him. First to play. For the purpose of clarity, Spanish words used in slogans will be translated in footnotes by the author.

6 Visit the new armanibeauty.es. The new [...]. 
combination was used in one commercial (Valentina. The new eau de parfum by Valentino) and English, Spanish and Italian in another (Visita armanibeauty.com Sì, il nuovo profumo. Giorgio Armani). This may be a means to express originality and attract attention. Supposedly, this trait has more to do with marketing strategies relying on ambiguous messages about the country of origin (Valozic 2015: 119-120).

As many as fifteen perfume commercials without any English words were identified, although almost all of them included English songs. These perfumes appear to be aimed at wealthy consumers attracted by carefully designed luxury articles, serving as symbols of distinction and social status. Thus, the six French-only perfume commercials in the corpus employed very expensive-looking and sophisticated images (e.g. Coco Mademoiselle Chanel; Dior Homme). Obviously, these perfumes are expected to be expensive, so the exclusivity and high-quality aspects of the brand are highlighted to justify the cost.

Five commercials with French-Spanish code-switching were also recorded (e.g. Tres tributos a la frescura. L'eau de Rochas; CH Eau de Parfum Sublime. La nueva fragancia de Carolina Herrera $)^{7}$. There is no clear reason why Spanish occurs together with French in the case of some perfumes and not in others, even with products of the same firm (Yves Saint Laurent). There was just one Italian-only commercial (Acqua di Gio. Giorgio Armani). Obviously, there is a perceived link between Italy, elegance, good taste, fashion and style (Bassat 2006: 188-189). This was observed for all language combinations in the corpus where Italian was present, clearly reinforcing the positive qualities of the advertised perfume. Interestingly, just three commercials were in Spanish only (trademarks owned by the Spanish firm Adolfo Domínguez), though they included English songs.

To sum up, out of the 56 perfume commercials, only 15 were not in English or without Anglicisms, although most of them had English songs or used Anglo-American fashion models. Somehow, the Anglo-American culture seems to be always present in the television commercials of perfumes in Spain, even in the case of French and Italian luxury perfumes. The list of pure Anglicisms compiled in this section is the following:

(3) beauty, city, design, euphoria, fragrance, hero, lady, license, list, love, lust, magnetism, men, million, note, person, phone, playboy, rebel, shape, sport, spray, superplayboy, tattoo, question, trademark, VIP, women, black, blue, brave, chic, delicate, delicious, discreet, excessive, first, free, golden, intense, light, masculine, new, original, pretty, pure, red, romantic, secret, sexy, unexpected, untold, wild, be, create, expect, forbid, go, know, make, measure, need, pick up, play, present, record, rephrase.

A total of 67 pure Anglicisms were recorded in 41 commercials. Most of them are associated with positive or persuasive connotations connected to the world of emotions (e.g. beauty, love, lust, magnetism, play). As Rodríguez Díaz (2011: 183) says, "pleasure, emotions and erotism are exploited in the commercials of perfumes". Emotional communication oriented to the needs of the consumer is fundamental in these products (Bassat 2006: 68). Other Anglicisms refer to the target consumers (lady, men, VIP, women, masculine) or the product itself, since many of these commercials are aimed at highlighting the design and aesthetics of the product (e.g. design, spray, original).

\subsubsection{Anti-aging and sun creams}

Pseudo-Anglicisms were especially significant in these product categories. Technical terms and neologisms were also abundant in the seventeen commercials which were compiled. According to Rodríguez Díaz (2011: 173), "advertisers introduce many linguistic innovations and neologisms

7 Three tributes to freshness [...] The new fragrance by [...].

8 Only nouns, adjectives and verbs will be considered. No pseudo-Anglicisms were found in the case of perfumes, clothes\&lingerie and sanitary towels\&tampons. 
and they become rapidly known. They use unusual resources to coin new words and break the norm to catch the attention of the consumer".

Hence, Anglicisms cause these terms to look attractive and scientific-like, even though consumers cannot understand them. They are usually invented by the advertiser's creative team and are new to the general public. These allusions to technology "confer prestige to the products. Being a source of positive connotations, scientific and technical jargon is typical in the advertising of certain products” (Rodríguez Díaz 2011: 181). The prestige of such technicisms is reinforced by the image of celebrities, but also researchers and other experts praising the benefits of the advertised creams are part of these commercials. This is the reason why unlike perfumes, English-only cream commercials were not found in the corpus (explanations in Spanish are always included). The following 35 pure Anglicisms and 8 pseudo-Anglicisms were detected:

(4) Pure Anglicisms: cleanser, complexion, cream, drug, effect, expert, food, mass, point, system, treatment, zone, new, supercleaning, total (Olay; USA); age, men, perfection, skin, perfect (L’Oréal; France); cosmetic [sic] (Somatoline; Italy); celebration, happiness, joy, night, therapy, blue (Biotherm; France); age, kit (Nivea; Germany); test (Vichy; France); sun (Delial; France); active, cellular (Nivea); complex, repair (Ecran; Spain).

Pseudo-Anglicisms: pro-xylane, Vitalift, Revitalift (L’Oréal); aquasource (Biotherm); Liftactiv (Vichy); Regenerist (Olay); anti-age (Nivea); after sun (Ecran; Spain).

In Spain, the market for anti-aging creams is clearly dominated by the French firm L'Oréal, the world's largest cosmetics multinational company, and its brands Biotherm and Vichy, which are specialised in luxury skin care articles. However, only Biotherm is using French, Spanish and English:

(5) Joie Bonheur Happiness Celebration Joy Biotherm. Blue Therapy Night disponible también para Aquasource y Skin?.

Spanish-English code-switching is present in the remaining commercials. Almost all the pure Anglicisms are nouns related to the features of the creams and their use (cleanser, complexion, skin, age, sun), the specialists' recommendations (treatment, zone, point, expert, test) and the excellence of results and their positive connotations (celebration, happiness, joy). Adjectives and verbs are used for similar purposes (new, supercleaning, cellular, perfect, repair). In this group of products, pseudo-Anglicisms consist of English-looking pseudo-scientific terms:

(6) Pro-xylane. This trademark, a hybrid originally created by Lancôme, is clearly intended to associate the cream components with the prestige of science.

Vitalift, Revitalift, Liftactiv. The names of these creams are formed with the verb lift, which in skin contexts is related to smoothness and absence of wrinkles, and the Latin noun vita meaning 'life'. The same applies to Liftactiv (activo means 'chemical element'; it is a typical Spanish term in advertising pseudo-scientific jargon).

Aquasource. It is a combination of Latin and English words also observed in the Spanish sports lexicon currently: aquagym, aquarelax (Rodríguez-Medina 2014: 418).

Regenerist. It seems to function as an euphemism meaning 'a product that serves to regenerate your skin'. The Spanish crema regeneradora would be an obvious allusion to old skin and age.

Anti-age. A variant of anti-aging.

After sun. A body cream to be used after sun-bathing, especially in case of sun burnt skin areas.

9 also available for. 


\subsubsection{The remaining products}

The corpus of pure Anglicisms and pseudo-Anglicisms found in the rest of the products are shown in the following table:

\begin{tabular}{|c|c|c|}
\hline PRODUCTS & PURE ANGLICISMS & PSEUDO-ANGLICISMS \\
\hline $\begin{array}{l}\text { Shampoos \& } \\
\text { hair products }\end{array}$ & $\begin{array}{l}\text { (21) advance (Llongueras; Spain); apple, care, casting, citrus, fresh (H\&S; } \\
\text { USA); baby, shampoo (Johson and Johnson; USA); essence, herbal (Clairol; } \\
\text { USA); gloss, repair, resist, hard, total (L'Oréal); look (Elnett, L'Oréal); pack } \\
\text { (Timotei, Unilever; Britain-The Netherlands); sensation, style, test (Garnier, } \\
\text { L'Oréal); spray (Pantene; USA). }\end{array}$ & (1) keraphyll (L’Oréal) \\
\hline Deodorants & $\begin{array}{l}\text { (13) Apollo, axe, pack (Axe; Unilever); cobalt, men, motion, protection, sense, } \\
\text { clear, maximum (Rexona; Unilever); dove (Dove; Unilever); stress, protect } \\
\text { (Nivea). }\end{array}$ & $\begin{array}{l}\text { (1) bio response } \\
\text { (Sanex; Colgate- } \\
\text { Palmolive, USA) }\end{array}$ \\
\hline $\begin{array}{l}\text { Razors \& } \\
\text { electric } \\
\text { shavers }\end{array}$ & $\begin{array}{l}\text { (17) Body, breeze, fusion, power, styler, test, styling, unlimited (Gillette; USA); } \\
\text { design, difference, skin, spa, make (Braun; Germany); innovation, panel, } \\
\text { symphony, touch (Philips; The Netherlands). }\end{array}$ & $\begin{array}{l}\text { (3) gyroflex (Philips), } \\
\text { proglide (Gillette), } \\
\text { silkepil (Braun) }\end{array}$ \\
\hline $\begin{array}{l}\text { Clothes \& } \\
\text { lingerie }\end{array}$ & $\begin{array}{l}\text { (10) beauty, footwear, shorts, be (elarmariodelatele.com; Spain); city, rock, } \\
\text { star, cute (Cife Spain Business; Spain); shop (Intimissi; Italy); facebook (Lidl; } \\
\text { Germany). }\end{array}$ & -------- \\
\hline $\begin{array}{l}\text { Toothpaste \& } \\
\text { mouthwash }\end{array}$ & $\begin{array}{l}\text { (8) zero (Listerine; USA); consumer, healthcare (GSK; UK); alcohol, free, new } \\
\text { (Oral-B; USA); repair, protect (Sensodyne; UK). }\end{array}$ & $\begin{array}{l}\text { odor-stop (Licor del } \\
\text { Polo Sp.); multi- } \\
\text { protection, pro-expert } \\
\text { (Oral-B) (3) }\end{array}$ \\
\hline $\begin{array}{l}\text { Health } \\
\text { products }\end{array}$ & $\begin{array}{l}\text { (6) spray (OTC; Spain); science, better, life (Bayer; Germany); chilly, } \\
\text { protect (Boston Group; Italy). }\end{array}$ & $\begin{array}{l}\text { (2) afterbite, repelbite } \\
\text { (Esteve; Spain) }\end{array}$ \\
\hline $\begin{array}{l}\text { Sanitary } \\
\text { towels \& } \\
\text { tampons }\end{array}$ & (5) cottonlike, pearl, (Evax; USA); evolution, pants, test (Ausonia; USA). & ------- \\
\hline $\begin{array}{l}\text { Mascara \& } \\
\text { make-up }\end{array}$ & $\begin{array}{l}\text { (11) accord, lash, midnight, false, non-stop, perfect (L'Oréal); boom, big, } \\
\text { beautiful (Astor; USA); eye, test (Maybelline, L'Oréal). }\end{array}$ & $\begin{array}{l}\text { (1) volum'express } \\
\text { (Maybelline) }\end{array}$ \\
\hline
\end{tabular}

Table 5. Pure Anglicisms and pseudo-Anglicisms in the remaining products

The expressive function of Anglicisms is evident in most pure Anglicisms found in the analysed commercials. Some of them are clearly related to positive sensations of freshness, smoothness, cleanliness and protection:

(7) fresh, care, gloss, herbal (shampoo and hair products); protection, sense (deodorants); breeze, symphony, touch (razors and electric shavers); cottonlike, pearl (sanitary towels and tampons).

Others are intended to confer prestige with references to design, strength, science and technology. This is the case with advance and test (shampoo and hair products), fusion and innovation (razors and electric shavers) and science (health products). The specific features of the products are also described with pure Anglicisms (e.g. baby, pack, spray, repair in shampoos and hair products).

Pseudo-Anglicisms are also used in the commercials for these articles. Thus, the Greek word bio, meaning 'life', commonly used as a prefix in science, can be found in Sanex's pseudo-Anglicism bio response. Typical pseudo-scientific advertising jargon was also observed with all the products, except for clothes, lingerie, sanitary towels and tampons (e.g. keraphyll, gyroflex, odorstop, afterbite, volum'express).

\section{Conclusions}

The present study takes a broader perspective on the influence of English and the Anglo-American culture on European Spanish, since it analyses a field unexplored so far, i.e. television commercials. The results confirm a considerable presence of pure Anglicisms, English-Spanish code 
switching, pseudo-Anglicisms and Anglo-American imagery and music in the advertising of products related to cosmetics, hygiene and personal care on Spanish television. Consequently, the link of these products to the prestige of the English-speaking world is reinforced.

Our results also coincide with those published in previous studies on Anglicisms in print media (Durán 2002, Van Hooft 2006, Gerritsen et al. 2007, Varey 2008, Rodríguez Díaz 2011, Valozic 2015). The reasons why Anglicisms are so frequently used in Spanish commercials were examined as well, and they were found to be rather complex and varied. The study shows that the success of English as a lingua franca in advertising is mainly due to the prestige and positive connotations of English in a globalised world where marketing and cost-saving strategies are favoured. The flexibility and sonority of English morphology to coin new terms play also an important role in the frequent use of English in Spanish commercials.

This current research also contributes some insights into the use of other European languages such as French and Italian in television commercials, which is an understudied aspect in publications on advertising in Spanish. We see that these foreign languages are also used alone or in combination with others in advertising some products such as the most expensive perfumes, as a result of their association with luxury, glamour and good taste in the Spanish perfume market. Nevertheless, the presence of these languages was insignificant in comparison to English in the case of those luxury products.

Finally, we believe that future research is needed to address gaps that remain unexplored (e.g. sociolinguistic surveys to examine the attitudes of Spanish speakers towards English in advertising, the analysis of the presence of English in some media such as social networks or sports betting sites).

\section{References}

Bassat, Luis 2006: El libro rojo de la publicidad. Barcelona: Random House.

Becksmith, Sandra 2008: Planes completos de publicidad. Barcelona: Deusto.

Durán Martínez, Ramiro 2002: La lengua inglesa en la publicidad española: una aproximación pragmática. PhD dissertation. Salamanca: Universidad de Salamanca.

García Morales, Goretti 2009: Análisis de los anglicismos léxicos del lenguaje cinematográfico registrados en muestras escritas entre 2002 y 2006. PhD dissertation. Las Palmas de Gran Canaria: Universidad de Las Palmas de Gran Canaria.

Gerritsen, M./Nickerson, C./Van Hooft, A./Van Meurs, F./Nederstigt, U./Starren, M./ Crijns, R. 2007: English in product advertisements in Belgium, France, Germany, the Netherlands and Spain. World Englishes 26/3, 291-315.

Gómez Capuz, Juan 1997: La madurez del anglicismo en español actual: el ejemplo de la lengua juvenil. In Lineros, Rocío et al. (eds.), Actas del V Encuentro de la Asociación de Jóvenes Lingüistas. Murcia: Servicio de Publicaciones de la Universidad de Murcia, 29-39.

González Cruz, Isabel/Rodríguez-Medina, María Jesús/Déniz Santana, María Jesús 2009: Anglicismos en el habla juvenil de Las Palmas de Gran Canaria. Madrid: La Factoría de Ediciones.

Hernández Toribio, María Isabel 2008: La lengua de la publicidad: algunas estrategias al servicio de la persuasión emocional. In Arroyo, Antonio (ed.), La lengua española en los medios de comunicación y en las nuevas tecnologías. Madrid: Laberinto, 222-299.

Lorenzo, Emilio 1971 (1955): El anglicismo en la España de hoy. In Lorenzo, Emilio, El español de hoy, lengua en evolución. Madrid: Gredos, 70-93.

Martínez Rodrigo, Stella 2005: El mensaje en la publicidad audiovisual. Aspectos y perspectivas del lenguaje publicitario. In Robles Ávila, Sara (ed.), Aspectos y perspectivas del lenguaje publicitario. Anejo LVI de Analecta Malacitana. Universidad de Málaga, 45-68.

Medina López, Javier 1996: El anglicismo en el español actual. Madrid: Arco Libros.

Pirulli, Marina 2004: La influencia de la lengua inglesa en el español contemporáneo. PhD dissertation. Bari: Università degli Studi di Bari.

Pratt, Chris 1980: El anglicismo en el español peninsular contemporáneo. Madrid: Gredos.

Rodríguez Díaz, José Antonio 2011: Anglicismos y germanismos en el lenguaje de la publicidad del español peninsular contemporáneo 1998-2007. PhD dissertation. Santiago: Universidad de Santiago de Compostela. 
Rodríguez González, Félix 2012: Anglicismos en el mundo del deporte: variación lingüística y sociolingüística. In Boletín de la Real Academia Española 92: 317-341.

Rodríguez González, Félix 1996: Functions of Anglicisms in Contemporary Spanish. In Cahiers de lexicologie 68,107128.

Rodríguez-Medina, María Jesús 2001: La influencia lingüística y sociocultural del inglés en España: el caso de la publicidad. In Muñoz, Carmen (ed.), Trabajos de lingüística aplicada. Barcelona: UniverBooks, 689-692.

Rodríguez-Medina, María Jesús 2003: La presencia del inglés en España: antecedentes y panorama actual. In Analecta Malacitana 13, 50-85.

Rodríguez-Medina, María Jesús 2014: Anglicismos en el léxico de las actividades deportivas de los gimnasios españoles. In Lexis 38, 401-427. Rodríguez Segura, Delia 1999: Panorama del anglicismo en español. Almería: Servicio de Publicaciones de la Universidad de Almería.

Valozic, Luiza 2015: El anglicismo léxico en la publicidad. Alicante: Publicacions Universitat D’Alacant.

Van Hooft Comajuncosas, Andreu. 2006: El valor añadido de los anglicismos en la publicidad española. El impacto y la valoración social de las voces inglesas en la publicidad de la revista Elle. In Calvi, Maria Vittoria/Chierchetti, Luisa (eds.), Linguistics Insights. Studies in Language and Communication. Nuevas Tendencias en el Discurso de Especialidad. Bern: Peter Lang. Bern, 225-248.

Varey, Gabriela 2008: An Investigation into the Use of English in Marketing Communications in Spain. MA dissertation. Oxford: Oxford Brookes University. 